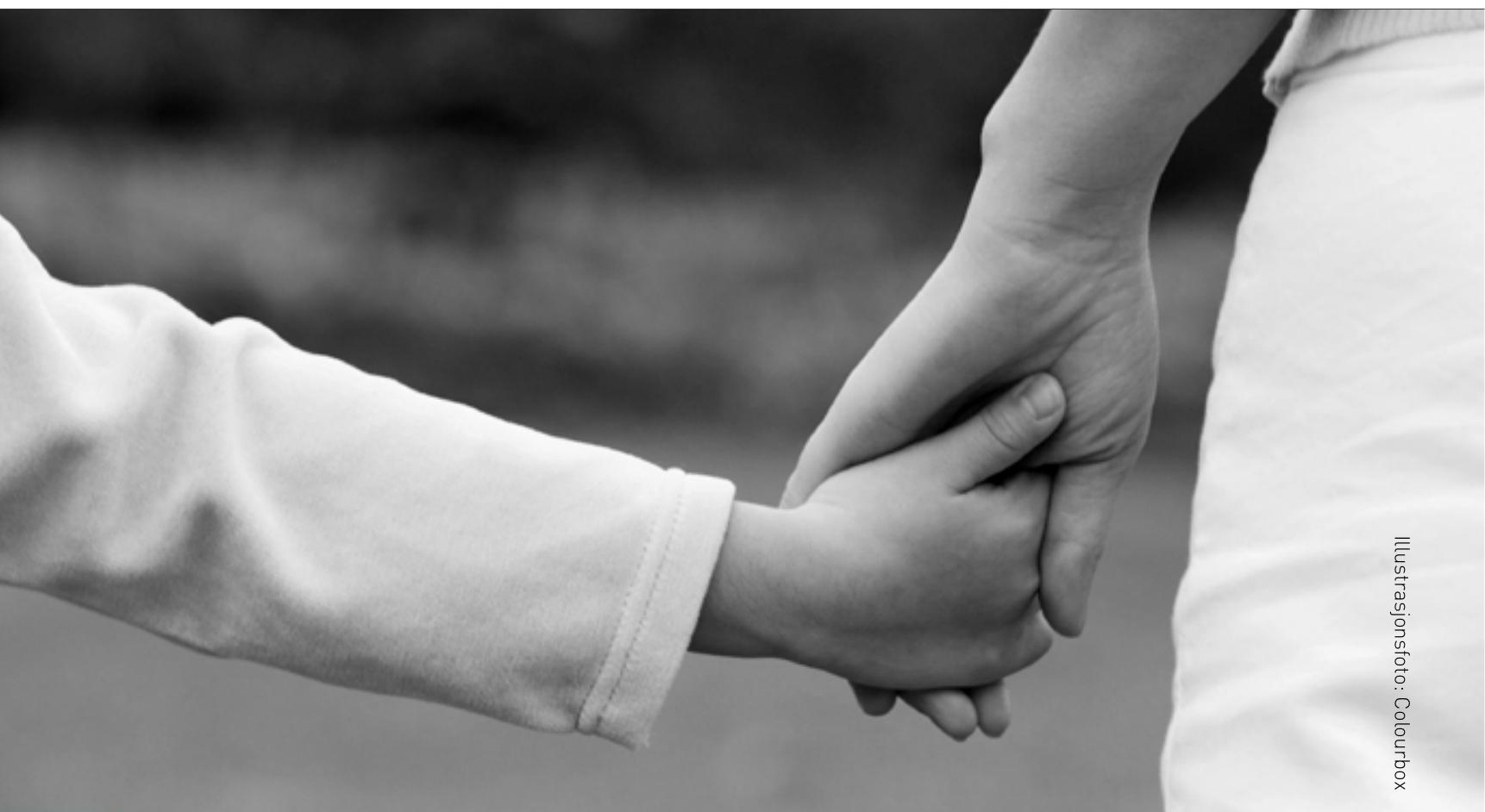

Bakgrunn: Det er en økende forståelse for hvor viktig det er med et familieperspektiv $\mathrm{i}$ behandling og rehabilitering av pasienter med psykisk lidelse. Det er gjennomført flere prosjekter som viser at informasjon og veiledning om psykisk lidelse bedrer kommunikasjonen innad i familien og reduserer konflikter. Det ble ikke funnet forskning som beskriver erfaringer ved å delta i parallelle grupper.

Hensikt: Denne kvalitative studien har som mål å beskrive foreldres oppfatninger av og erfaringer med å delta i parallelle gruppesamlinger, når en av foreldrene har en psykisk lidelse.

Metode: Vi benyttet et kvalitativt eksplorativt deskriptivt design med en fenomenografisk tilnærming. Fire foreldrepar ble intervjuet to ganger. I dataanalysen er det tatt utgangspunkt i Alexandersons fire faser.

Resultater: I analysen framkom det fire beskrivningskategorier. Informantene opplevde gruppesam- lingene som unike, befriende og nyttige for hele familien. Informantene i studien hadde ulike erfaringer og opplevelser i møte med psykisk helsevern, og samtlige ønsket mer informasjon og veiledning.

Konklusjon: Parallelle gruppesamlinger for foreldre og barn har vist seg å ha vært en positiv opplevelse for familien. Det sentrale i studien, og som ble fremhevet som viktig av informantene, er at gruppesamlingene for foreldre og barn foregikk samtidig på samme sted.
Background: There is a growing understanding of the importance of having a family perspective in treatment and rehabilitation of patients with mental illness. We have carried out several projects showing that information and guidance on mental illness improves communication within the family and reduces conflicts. We did not find any research that describes experiences while participating in parallel groups.

Objective: The aim of this study was to describe the opinions and experiences of parents - where one of them is suffering from mental ill- ness - participating in parallel group sessions.

Method: A qualitative exploratory and descriptive design with a phenomenographic approach to the pairs of parents interviewed has been used. Four pairs of parents were interviewed. The data analyses are based on Alexanderson>s four phases.

Results: In the analysis, four description categories emerged. The informants experienced the group sessions as unique, liberating and useful for the whole family. The informants in the study had different experiences with the mental health care, and all wanted more information and guidance.

Conclusion: Where one parent has a mental disorder, a parallel group meeting for parents and children has been shown to be a positive experience for the family. The central aspect of our study that parents have emphasised as important is that the group sessions for parents and children were at the same time and place.

Keywords: Discussion groups, mental illness, parents, children. 


\section{» Familieperspektiv i psykisk helsevern}

Forfattere: Monica Solberg

og Geir Berg

\section{NøKKELORD}

- Samtalegruppe

- Psykisk lidelse

- Foreldre

- Barn

\section{INTRODUKSJON}

Biomedisinsk tenkning og tradisjon har dominert forståelsen av diagnostisering og behandling av sykdom og lidelse i Norge helt fram til vår tid. Behandlingen av psykiske lidelser bar preg av oppbevaring i institusjoner, og psykiatriske pasienter kunne være inneliggende i årevis. Et annet aspekt ved den medisinske tradisjonen var en individfokusert tilnærming til psykiske lidelser generelt. Familien var i liten grad involvert i behandlingen og følte seg ofte maktesløse når de prøvde å forstå og hjelpe den psykisk syke personen med hans eller hennes lidelse (1).

Gjennom stortingsmeldinger, lovverk, retningslinjer og politiske beslutninger har man lagt føringer som berører personer med psykiske lidelser og deres pårørende (2-4). Det overordnete målet er å skape et helhetlig behandlingstilbud.
Pasientens sosiale nettverk og familien er sentrale i behandlingsoppfølgingen. Man kan se en endring fra et individorientert behandlingsperspektiv til et mer systemorientert perspektiv eller familieperspektiv. Behandlingen av personer med psykiske lidelser skal nå i størst mulig grad skje nær pasientens bosted (5). Pasientene får kortere liggetid i spesialisthelsetjenestens institusjoner og blir raskere tilbakeført til sin hjemkommune for videre oppfølging. For å oppnå en raskere effekt vil det ha stor betydning at pårørende involveres i behandlingen av pasienten (2-4).

Siden midten av 50-tallet har det blitt gjennomført en mengde studier om hvordan familien påvirkes av at et medlem er psykisk sykt (6). Pårørende befinner seg ofte $\mathrm{i}$ en todelt situasjon. På den ene siden skal de være en støtte for den som er syk, både i behandlingssammenheng og i dagliglivet. På den andre siden trenger også pårørende og nærpersoner støtte (7). Når et familiemedlem blir rammet av alvorlig sykdom, har de som står nær personen behov for informasjon, veiledning og konkrete råd. Mange pårørende opplever ofte denne situasjonen som så kaotisk og uhåndterlig at de føler seg hjelpeløse (7).

Forskningen frem til nå gir grunnlag for å si at det ikke er foreldrenes psykiske lidelse i seg selv som er skadelig for barnets helse og utvikling, men hvilken atferd foreldrene har sammen med barnet. Grøsfjeld (8) hevder, med bakgrunn i tidligere forskning, at atferd er mulig å endre. Og at man gjennom veiledning til foreldrene om deres atferd kan bidra til denne endringen. Barn som klarer seg bra

\section{Hva tilfører artikkelen?}

Parallelle gruppesamlinger for foreldre og barn, når en av foreldrene har en psykisk lidelse, var en positiv opplevelse for foreldrene.

\section{Mer om forfatterne:}

Monica Solberg er psykiatrisk sykepleier, prosjektleder og rådgiver ved Sykehuset Innlandet, Stab Helse - Avdeling for Kvalitet og Pasientsikkerhet. Geir V. Berg er forskningsveileder ved Sykehuset Innlandet, Divisjon Lillehammer og førsteamanuensis ved seksjon for helse, teknologi og samfunn, Høgskolen i Gjøvik. Kontaktperson: monica.solberga sykehuset-innlandet.no 
til tross for foreldrenes psykiske lidelse, har som regel hatt en annen voksen å forholde seg til. Barn av foreldre med en psykiske lidelse er i utgangspunktet friske barn, men trenger støtte og/eller hjelpetiltak for å forebygge en eventuell utvikling av psykiske lidelser senere i livet (9-11)

Wang og Goldschmidt (12) konkluderer med at de fleste foreldre ønsker at behandler skal studien gjorde vi litteratursøk med følgende søkeord: "child», "parents», «family group", «parallell group» og «mental illness». Vi fant flere rapporter som beskriver pårørende, voksne eller barn, og den med psykisk lidelse sine erfaringer ved å delta i separate grupper $(16,17)$. Videre fant vi studier som omhandlet flerfamiliegrupper, hvor flere familier er samlet

\section{Gruppesamlingene var unike, befriende og nyttige.}

snakke med dem om deres barn, og om hvordan de fungerer som foreldre. Dette bekreftes i flere studier $(13,14)$. Videre opplever foreldre at fagfolk i liten grad tar opp barn som tema. Dette fører til at de selv synes det blir for vanskelig å snakke om (15).

Det er igangsatt flere tiltak for å forebygge utvikling av psykisk lidelse hos barn med psykisk syke foreldre i Norge de senere årene. Det dreier seg om gruppetilbud for pårørende, for eksempel samtalegrupper for voksne ellere barn (16). Høsten 2009 ble det etablert et samarbeidsprosjekt mellom et helseforetak, tre omliggende kommuner, Barnas Stasjon og Mental Helse. Samarbeidsprosjektet fikk navnet «BAPS-foreldre». Man skulle sette i gang parallelle gruppesamlinger for foreldre og deres barn, hvorav en av foreldrene hadde en psykisk lidelse. Temaene i gruppesamlingene var bestemt på forhånd. Eksempler på temaer var: Kunnskap om psykisk lidelse og dens virkning på familien, opplevelse av skyld, skam og ansvar. Foreldre og barn hadde de samme temaene i sine gruppesamlinger.

I forberedelsene til denne i en og samme gruppe $(14,18)$. Vi fant ikke studier som beskriver eller analyserer hvordan foreldre har opplevd å delta i parallelle grupper.

Parallelle gruppesamlinger innebærer at foreldre og barn er i separate samtalegrupper, men på samme sted til samme tid. Vi utførte et nytt søk høsten 2014 med samme søkeord, og det ble ikke funnet noen studier som omhandlet parallelle grupper.

Hensikten med studien var å beskrive foreldres oppfatning og erfaringer ved å delta i parallelle gruppesamlinger når en av foreldrene har en psykisk lidelse.

\section{METODE}

Studien har et deskriptivt eksplorativt kvalitativt design med en fenomenografisk tilnærming. Fenomenografisk tilnærming søker å beskrive og undersøke variasjonen i menneskers oppfatning av ett og samme fenomen. Hensikten er å forstå menneskers opplevelser, erfaringer og holdninger $(19,20)$. Dette gjøres gjennom å beskrive bredde og variasjon i oppfatninger av ett fenomen. Man skiller mellom det som kan observeres utenfra, konstatere at noe er; første ordensperspek- tiv, og hvordan noe oppfattes å være; andre ordensperspektiv. Fenomenografien har som mål å beskrive hvordan mennesker oppfatter fenomenet i omverdenen (19).

\section{Rekruttering og utvalg}

Fire kommuner og to døgnavdelinger i spesialisthelsetjenesten ble kontaktet. Fem foreldrepar ble rekruttert, og fire fullførte. Inklusjonskriterier var at en av foreldrene har eller har hatt psykiske vansker og vært i kontakt med voksenpsykiatrien. Den andre omsorgspersonen skulle være den som ivaretok barnet når mor eller far ikke var i stand til det. Informantene skulle forstå og snakke norsk og ha samtykkekompetanse. Hovedstudien undersøkte både foreldrenes og barnas deltakelse i BAPS-foreldreprosjektet, men i denne artikkelen handler det om foreldrene.

\section{Datainnsamling og analyse}

Det fenomenografiske intervjuet ble gjennomført med støtte av en semistrukturert intervjuguide. Intervjuene var preget av en uformell og dialogisk form knyttet til forskningstemaet. Oppfølgingsspørsmål ble brukt systematisk for å få mer utdypende svar fra informanten der det var behov for $\operatorname{det}(20,21)$.

Det ble gjennomført to parintervjuer av hvert foreldrepar, til sammen åtte intervjuer. Første intervju ble gjennomført etter fjerde gruppesamling. Her var inngangsspørsmålet i intervjuet: «Hvilke oppfatninger og erfaringer har du/dere med å delta $\mathrm{i}$ gruppesamlinger?».

Det andre intervjuet ble gjennomført etter siste gruppesamling (samling 8). Her var inngangsspørsmålet: «Hvilke 
oppfatninger og erfaringer har du/dere hatt ved å delta i gruppesamlingene?» I det andre intervjuet ble utsagn fra det første intervjuet fulgte opp. Ved et av parintervjuene møtte kun en av informantene. Partneren hadde meldt forfall.

Fire av parintervjuene ble gjennomført i lokalene hvor de hadde gruppesamlinger. Etter ønske fra informantene ble de fire øvrige intervjuene gjennomført i et lokale nær informantenes bosted. Intervjuene varte fra 20-40 minutter.

Intervjuene ble tatt opp med digitalopptaker og transkribert ordrett. Analysen ble gjennomført i fire faser inspirert av Alexandersson (22). I første trinn ble samtlige parintervjuer lest for å kunne danne seg et helhetsinntrykk og oversikt. I andre trinn gikk vi igjennom samtlige utsagn i intervjuene. Utsagn som var i henhold til studiens hensikt, ble identifisert og kodet med nummer. I tredje trinn gjennomgikk vi samtlige utsagn og kondenserte meninger for å se etter likheter og ulikheter av oppfatningene. Oppfatningene ble kategorisert og dannet beskrivningskategorier. I det fjerde trinnet var hensikten å søke etter den underliggende strukturen i oppfatningene (22). Forholdet mellom beskrivningskategoriene ble analysert, og en hierarkisk struktur trådte fram.

\section{Forskningsetisk vurdering}

Studien ble godkjent av REK. Studien rettet seg direkte mot foreldre og barn som kan ha vært i en belastende situasjon på grunn av at et familiemedlem har en psykisk lidelse. Det ble derfor lagt stor vekt på valg av metode, informasjonsmengde og hvordan intervjusi- tuasjonen skulle gjennomføres. Det var gjort en avtale med spesialisthelsetjenesten ved et helseforetak i tilfelle noen av informantene hadde behov for en samtale i etterkant av intervjuene.

\section{RESULTATER}

Studiens hensikt var å søke etter informantenes oppfatninger av og erfaringer med å delta i parallelle gruppesamlinger. Funnet i parintervjuene kan oppsummeres i fire beskrivningskategorier: En overordnet beskrivningskategori: "Gruppesamlingene var unike, befriende og nyttige», og tre beskrivningskategorier: «Dele erfaringer», «Tydeliggjøring av roller og posisjoner» og «Oppdage, lære og erkjenne».

\section{Gruppesamlingene}

Den overordnede beskrivningskategorien sier hvordan deltakerne oppfattet og erfarte gruppesamlingene som unike,

else for psykisk lidelse og hvordan dette kan påvirke familiens ulike medlemmer.

En mor beskriver sin er erfaring etter gruppesamlingene slik: "Vi gjør ikke noen dårligere jobb enn alle andre foreldre når det gjelder våre barn. Det er greit å snakke med unga om problemer og sånne ting, (...) du trenger ikke å skjerme dem og beskytte dem, for dem forstår allikevel».

\section{Dele erfaringer}

Denne beskrivningskategorien var basert på fire kategorier: Bli sett og hørt, snakke og lytte, få råd og tips, og få støtte og aksept

Å dele erfaringer hadde betydning for relasjonsdannelsen til de andre i samtalegruppa og i familien. Foreldre med en psykisk lidelse hadde tidligere ikke fătt tilbud fra sin behandler om å ha med seg sin partner og/eller sine barn til samtale.

Det å få råd og tips av andre foreldre eller gruppeleder var viktig for

\section{Det å få råd og tips av andre foreldre eller gruppeleder var viktig for eget utbytte.}

befriende og nyttige. Foreldrene beskrev organiseringen av gruppesamlingene som unik, ved at hele familien var inkludert, og at samlingene for foreldre og barn gikk parallelt. $\AA$ møte andre foreldre og deres barn som lever med psykisk lidelse i familien var befriende. Tydeliggjøring av roller og posisjoner innad i familien ble viktig ved at de følte seg tryggere på hverandre. Det nyttige var å dele erfaringer med andre som var i liknende situasjon som dem selv. Foreldrene uttrykte at de hadde oppdaget og erkjent nye sider ved seg selv og sin partner. De hadde også tilegnet seg kunnskap og forstå- eget utbytte av gruppesamlingene. Dette handlet om hva de kunne fortelle barna og på hvilken måte de skulle forklare hva en psykisk lidelse var, slik at barna kunne forstå. En mor beskrev endring i forståelse hos barnet slik: «Han lar meg være i fred, så finner han på noe annet sammen med far, eller at han sitter hos meg og stryker meg på håret, og sier: Er det noe jeg skal hjelpe deg med mamma? Han er veldig mye mer omtenksom, så han skjønner nok at jeg ikke er lat, men at jeg er syk».

\section{Tydeliggjøring av roller}

Denne beskrivningskategorien er basert på fem kategorier: 
Være foreldre med en psykisk lidelse, være pårørende, være foreldre, være mor og være far.

Deltakelse i gruppesamlingene gjorde informantene med en psykisk lidelse bevisste på hvilken rolle de hadde i familien. Underveis i gruppesamlingene innså de at deres partner ikke hadde forstått det de prøvde å formidle. En informant beskrev erfaringen sin med partnerens forståelse på følgende måte: «Jeg måtte til slutt innse at uansett hva jeg prøvde å fortelle ham angående min depresjon, så skjønte jeg jo at jeg ikke oppnådde noen ting. Han skjønte det ikke, og da ble jeg mer deprimert og utenfor på grunn av det, og jeg hadde mest lyst til å gi opp. Jeg prøvde å forklare at han måtte være mer ønsker og det å se «nye» sider hos hverandre.

Før oppstart av gruppesamlingene var det tvil om hvilken nytte familien kunne ha av å delta $\mathrm{i}$ åtte gruppesamlinger. Hvor mye kunnskap ble tilegnet, og hvilke endringer kunne skje på så kort tid? Dette endret seg underveis. En av de pårørende beskrev denne endringen slik: «Når jeg nå ser tilbake, så har det liksom gjort underverker. Man sier jo at Jesus gikk på vannet, så en begynner jo å tro på dette egentlig. En får ta tilbake barnetroen».

Ny kunnskap var oppstått gjennom det å oppdage, lære og erkjenne. Informantene fikk kunnskap om hvordan det var å ha en psykisk lidelse og det å være pårørende. I tillegg

\section{Det nyttige var å dele erfaringer med andre som var i liknende situasjon som dem selv.}

til stede og være der med meg, men det hjalp ikke».

Ved oppstart av gruppesamlingene uttrykte pårørende stor grad av frustrasjon over å ha en partner med en psykisk lidelse. Dette påvirket deres rolle og posisjon som pårørende i familien. En pårørende beskriver denne opplevelsen slik: «Før vi gikk inn i denne gruppa, så hadde jeg rett og slett ikke peiling på hva som var riktig eller galt i hvordan jeg skulle forholde meg til min partner. Så det har rett og slett vært som natt og dag for min del».

\section{Oppdage, lære og erkjenne}

Denne beskrivningskategorien er basert på fire kategorier: $\mathrm{Ny}$ kunnskap, endret forståelse, oppmerksom på egne behov og

fikk de kunnskap om hvordan de skulle forklare og svare på vanskelige spørsmål fra barna. En pårørende beskrev det slik: "Jeg har lært mye mer i forhold til hennes tilstand og hvordan jeg skal forholde meg når hun er syk. For eksempel hvordan hun reagerer og hva jeg skal forta meg. Dette har jeg vært usikker på hele tiden. Skal jeg gå unna? Skal jeg sette meg å prate med henne? Eller hva skal jeg gjøre?».

\section{DISKUSJON}

Foreldrene i studien ga uttrykk for at å delta i gruppesamlingene hadde hatt betydning for dem som familie. Det kom fram at de ikke ville hatt samme utbytte hvis barna ikke hadde vært med. I BAPS-foreldre var inklusjonskriteriene at forelderen med en psykisk lidelse og en pårørende skulle delta . Erfaringer fra andre studier hvor flere familiemedlemmer deltar i samtalen har vist seg å ha betydning $(17,23,24)$. Hos McFarlane (23) framkom det at flerfamiliegrupper hadde bedre effekt enn singel- eller familiestøtte. Resultatene viste at flere av dem som hadde deltatt i flerfamiliegruppe var i arbeid, og de håndterte kriser på en bedre måte enn dem som hadde mottatt singel-familiestøtte. Svendsen (17) gjennomførte en evaluering av BAPP-programmet hvor det hadde vært frivillig for foreldrene å delta. Frivilligheten hadde medført at det var foreldre uten psykisk lidelse som hadde møtt i gruppesamlingene, og ikke foreldrene med en psykisk lidelse. I BAPP-programmet var det åtte samlinger for barna hvor temaene var bestemt på forhånd, og kun to samlinger for foreldrene. Samlingene for foreldrene var i starten og slutten av tidsperioden for gjennomføring av barnegruppene. Formålet var å informere foreldrene om hva barna hadde lært og øke deres forståelse for barnas situasjon (17).

De pårørende i studien manglet kunnskap om psykisk lidelse. Det kom fram i samtalegruppa. Manglende kunnskap hadde bidratt til frustrasjon og en opplevelse av merbelastning for de pårørende. Dette samsvarer med erfaringer fra andre studier $(25,26)$. Greenberg og medforfattere (25) fant at å informere pårørende og gi dem økt kunnskap om psykisk lidelse var viktig. Ved at pårørende fikk denne kunnskapen opplevde de redusert belastning ved å leve med en partner eller 
et familiemedlem med en psykisk lidelse (27).

Foreldrene i studien hadde etter å ha deltatt i samtalegruppa blitt oppmerksomme på at deres behandler ikke hadde tatt opp temaer knyttet til det å være foreldre. De hadde et ønske om at behandler skulle snakke med dem om barna. Liknende erfaringer beskrives i flere studier (13,28-31). Mødrene hos Mevik og Trymbo (13) mente at det barn ikke vet, har de ikke vondt av. Etter å ha deltatt i samtalegruppa, hadde informantene endret oppfatningen om hva barn kan bli fortalt. Mevik og Trymbo (13) henviser til en studie gjennomført av Dundas og Wormnes (1992) hvor fagfolk hadde en oppfatning av at barn først og fremst burde skånes fra det vanskelige i livet.

Erfaringer fra vår studie viste at ved å delta i gruppesamlingene hadde foreldre med en psykisk lidelse tilegnet seg kunnskap om hvordan de kunne snakke med barna om å være psykisk syk. Dette handlet om hvordan informere om ulike sider ved det å ha en psykisk lidelse, slik at barna forstår. Foreldrene opplevde at barna følte mer trygghet, og at de forsto at det ikke var deres skyld at mor eller far var psykisk syk. Dette samsvarer med funn $\mathrm{i}$ andre studier $(13,14,32)$. Ahlgreen (29) fant at helt tilbake i 1994 var det påvist at mange psykiatriske pasienter $(50-70$ prosent) var bekymret for sine barn. Prosjektet «Kontakt med børn af psykiatriske patienter» og flere andre utviklingsprosjekter har senere vist at pasienten er opptatt av hvordan deres egne barn har det $(12,13,31)$.

Pårørende i denne studien beskrev en endring i kommuni-

kasjon og samhandling i familien etter å ha deltatt i parallelle grupper. Endringen besto i økt forståelse for hvordan den andre hadde det, og samhandlingen var preget av mindre konflikter. Dette samsvarer med funn

drene har en psykisk lidelse, har vist seg å ha vært en positiv opplevelse for foreldrene. Det sentrale i vår studie, som foreldrene har fremhevet som det viktigste, er at gruppesamlingene for foreldre og barn var på samme sted, tid, og

\section{Informantene endret oppfatningen om hva barn kan bli fortalt.}

i andre studier $(7,23,26)$. Samarbeid med de pårørende hvor man vektlegger undervisning, informasjon og veiledning, kan redusere negativ samhandling i familien og virke frigjørende for det enkelte familiemedlem (26).

\section{Metodekritikk}

Funnene fra studien er basert på erfaringer fra et lite antall informanter. Utvalget er derfor ikke representativt for alle familier hvor en av foreldrene har eller har hatt en psykisk lidelse. Samtidig representerer informantene i denne studien en variasjon i bosted og erfaring med psykisk helsevern. Overførbarheten i denne studien mener vi likevel er mulig i en tilsvarende kontekst med et tilsvarende utvalg.

I diskusjonen er det henvist til prosjekter og bøker, og lite til annen forskning. Bakgrunnen for dette er at det er gjort lite forskning på parallelle grupper.

\section{KONKLUSJON}

Ut fra de erfaringer som er gjort i denne studien, ser vi nytten og verdien av et nært og tett samarbeid mellom de ulike nivåene i behandlingskjeden innenfor psykiske helsevern, og de som er naturlige samarbeidspartnere, som skole, SFO og barnehager.

Parallelle gruppesamlinger for foreldre og barn, når en av forel- hadde like temaer i samlingene. Dette førte til at det var enklere å prate sammen om de vanskelige temaene innad i familien.

Denne studien viser behovet for videre forskning hvor man fokuseres på familieperspektivet i psykisk helse. Det kunne være nyttig i forskningsøyemed å igangsette liknende studier hvor barna blir inkludert. Hensikten bør være å vektlegge de ulike deltakernes oppfatninger og erfaringer ved å delta i parallelle samtalegrupper.

Takk til Wenche Westby Larson for godt samarbeid med masteroppgaven, som er grunnlaget for denne artikkelen.

\section{REFERANSER}

1. Haugsgjerd S, Jensen P, Karlsson B, Løkke JA. Perspektiver på psykisk lidelse: Å forstå, beskrive og behandle. Oslo: Gyldendal akademisk; 2009.

2. Sosial- og Helsedirektoratet. Oppfølgning av barn til psykisk syke og/eller rusavhengige. 2006.

3. Regjeringen. Sammen om psykisk helse: Regjeringens strategiplan for barn og unges psykiske helse. Oslo: Helsedepartementet; 2003.

4. Sosial- og helsedepartementet. Utskrevet til mor: Pårørende til mennesker med psykiske lidelser. Oslo: Sosialog helsedepartementet; 1995.

5. Thorn A, Holte A. Diagnose bipolar affektiv lidelse: Foreldres erfaring. Oslo: Nasjonalt folkehelseinstitutt; 2006.

6. Engmark L, Holte A, Alfstadsæther B.

Diagnose schizofreni: Foreldres erfaring. Oslo: Nasjonalt folkehelseinstitutt; 2006. 7. Bøckmann K, Kjellevold A. Pårørende i helsetjenesten: En klinisk og juridisk innføring: Fagbokforlaget; 2010. 
8. Grøsfjeld M. Pasientens barn-psykologens ansvar? En drøfting av etiske prinsipper. Tidsskrift-Norsk Psykologforening. 2004:41(11):900-6.

9. Fudge E, Mason P. Consulting with young people about service guidelines relating to parental mental illness. Australian e-Journal for the Advancement of Mental Health. 2004;3(2):50-8. 10. Maybery D, Ling L, Szakacs E, Reupert A. Children of a parent with a mental illness: perspectives on need. AustraLian e-Journal for the Advancement of Mental Health. 2005;4(2):78-88.

11. Reupert A, Maybery D. Families affected by parental mental illness: A multiperspective account of issues and interventions. American Journal of Orthopsychiatry. 2007;77(3):362-9.

12. Wang A, Goldschmidt V. Interviews with psychiatric inpatients about professional intervention with regard to their children. Acta Psychiatrica Scandinavica. 1996:93(1):57-61.

13. Mevik K, Trymbo BE. Når foreldre er psykisk syke. Oslo: Universitetsforlaget; 2002.

14. Beardslee WR. Out of the darkened room: when a parent is depressed: Protecting the children and strengthening the family. Boston: Little, Brown and Company; 2002.

15. Aamodt LG, Aamodt I. Tiltak for barn med psykisk syke foreldre: rapport. [Oslo]: Regionsenter for barn og unges psykiske helse, Helseregion Øst og Sør; 2005.

16. Halsa A, Aubert A-M. Forebyggende arbeid når mor eller far har psykiske helseproblemer Lillehammer: Høgskolen i Lillehammer; 2009.
17. Svendsen A. Forebyggende arbeid med barn av foreldre med psykisk sykdom og rusproblemer: En evaluering av BAPP-programmet. Dragvoll: Barnevernets utviklingssenter i Midt-Norge; 2004.

18. Riley A, Valdez C, Barrueco S, Mills C, Beardslee W, Sandler I, et al. Development of a family-based program to reduce risk and promote resilience among families affected by maternal depression: Theoretical basis and program description. Clinical Child and Family Psychology Review. 2008;11(1):12-29.

19. Marton F, Booth S. Learning and awareness. Mahwah, N.J.: Lawrence Erlbaum; 1997.

20. Kroksmark T. Fenomenografisk didaktik. Göteborg: Acta Universitatis Gothoburgensis; 1987.

21. Kvale S, Brinkmann S, Anderssen TM, Rygge J. Det kvalitative forskningsintervju. Oslo: Gyldendal akademisk; 2009.

22. Alexanderson M. Den fenomenografiska forskningsansatsens fokus. I: Starrin B, Svensson P-G, editors. Kvalitativ metod och vetenskapsteori. Lund: Studentlitteratur; 1994. s. 111-36.

23. McFarlane WR. Multifamily groups in the treatment of severe psychiatricdisorders. New York: Guilford Press; 2002. 24. McFarlane W, Dixon L, Lukens E, Lucksted A. Family psychoeducation and schizophrenia: A review of the literature. Journal of Marital and Family Therapy. 2007;29(2):223-45.

25. Greenberg J, Gkeenley J, Brown R. Do mental health services reduce distress in families of people with serious mental illness? Psychiatric Rehabilitation Journal. 1997;21:40-50.

26. Smeby NA. Samarbeid med familien i psykiatrien. I: Kirkevold M, Ekern KS, editors. Familien i sykepleiefaget. Gjøvik: Gyldendal Akademiske; 2001. s 108-29.

27. Nordby K, Kjønsberg K, Hummelvoll J. Relatives of persons with recently discovered serious mental illness: in need of support to become resource persons in treatment and recovery. Journal of psychiatric and mental health nursing. 2010;17(4): 304-11.

28. Wang A, Goldschmidt V. Interviews of psychiatric inpatients about their family situation and young children. Acta Psychiatrica Scandinavica. 1994;90(6):45965.

29. Ahlgreen B. Kontakt med børn af psykiatriske patienter - et udviklingsprojekt i Psykiatrien i Århus Amt, Vestregionen; Evalueringsrapport maj 2000. Århus: Psykiatrien i Århus Amt; 2000.

30. Halsa A. «Mamma med nerver»: en studie av moderskap og barneomsorg i velferdsstaten, når mor har psykiske helseplager. Trondheim: Norges teknisknaturvitenskapelige universitet; 2008.

31. Halsa A, Aubert A-M. Forebyggende arbeid når mor eller far har psykiske helseproblemer: en evaluering av det forebyggende arbeid for barn med psykisk syke foreldre i Asker og Bærum. Lillehammer: Høgskolen; 2009.

32. Solberg A. Hjelp til barn som har foreldre med psykiske lidelser: Evaluering av prosjektet og virksomheten «Du er ikke den eneste» - Et gruppetilbud med psykopedagogisk tilnærming til barn og unge som har foreldre med psykisk lidelse. Oslo: Instituttet; 2003. 